\title{
The Diaries of Mary Seton Watts (1849-1938) in the Archives at Watts Gallery, Surrey
}

\author{
Lucy Ella Rose \\ University of Surrey
}

Mary Seton Watts (née Fraser-Tytler, 1849-1938) was a pioneering professional woman artist, ceramicist, and designer, married to the famous Victorian painter and sculptor George Frederic Watts (1817-1904). While her life and work have long been overshadowed by the dominant critical focus on her husband, she designed rugs and pots for Liberty of London and became a famous name in the Arts and Crafts movement. ${ }^{1}$ She was also a writer and prolific diarist, although her diaries have never before been studied. ${ }^{2}$ Mary's eight extant annual diaries were written between 1887 and 1908, covering her marital years and a few years after her husband's death. ${ }^{3}$ This time period was the pinnacle of George's reputation as Britain's premier portrait-painter and "England's Michelangelo."4 The Wattses became celebrities during their lifetimes and were highly respected in intellectual, aristocratic, artistic, and literary circles. They were much admired by their famous forward-thinking contemporaries and became close friends with figures such as the writer and women's suffrage supporter George Meredith (1828-1909) and the British feminist Josephine Butler (1828-1906); Mary's diaries document their fascinating interactions and discussions. Her diaries also offer unprecedented insight into the Wattses' personal and professional relationship as well as their progressive sociopolitical positions and feminist affiliations and are thus of great cultural importance.

I worked on the almost entirely unexplored Mary Watts archive for three years (2011-2014) as a condition of my doctoral studentship, awarded by the School of English at the University of Surrey and Watts Gallery (Compton, Surrey) in their first collaboration. Mary's diaries have been in the collection of Watts Gallery for over a hundred years and reside in the John George Archive Room, where I transcribed five of them using a diary stand and magnifying equipment. ${ }^{5}$ The archive at Watts Gallery encompasses letters, photographs (including the Rob Dickins Collection of over 4,000 photographs and manuscript letters relating to leading Victorian cultural figures), diaries, historical and oral history records, drawings, and sketchbooks created by or related to the Wattses. Mary's miniscule diary writing - which adds an air of intimacy to the small pages—was often difficult to decipher, especially at first, but I became accustomed to her 
handwriting and lexis. The difficulty of transcribing her diaries was exacerbated by the fact that many pages have been stuck together or cut out in an apparent act of (self-)censorship or as part of a posthumous editing process that shrouds the diaries in a sense of mystery and secrecy. Yet it is clear that Mary's diaries provided her with private imaginative and intellectual spaces as well as spaces of artistic inception, where she developed ideas for her designs in word and image; the result is a rich palimpsest of prose, verse, and drawing. Streams of consciousness, fragmentation, broken syntax, unruly punctuation, ellipses, and open endings pervade-and are characteristic of-Mary's diary writing.

Since my dissertation-titled "Women in Nineteenth-Century Creative Partnerships: The 'Significant Other"'-was to some extent a feminist project of recovery focusing on historically neglected female figures, I searched Mary's diaries for evidence of the Wattses' creative partnership and Mary's empowered role within it, as well as for any evidence of her support of early feminism. Evidence of the former was more easily found. Mary's account of her professional artistic career punctuates her ostensibly conventional wifely narrative, and her diary writing reveals her role as a respected artistic equal and intellectual companion to George, challenging traditional views of the Wattses as representatives of patriarchal power relations. The latter required much more time-consuming interrogation of her diaries, but I found that Mary engages with women-centered and gender-related issues in various - if not immediately obvious or conspicuous-ways (for example, in her ideas for her designs, her philanthropic projects, and her discussions with visitors). Mary's strongest expressions of feminist feeling appear in her diaries of 1893 and 1896 and most explicitly in 1893 during a discussion with Meredith on the place of women. Read together, Mary's long-forgotten diaries reveal the emergence of a strong female and feminist voice, painting a picture of a woman who believed in coeducation, gender equality, women's rights, and female liberation; she achieved and promoted greater sociopolitical freedom through her professional creative practice and partnership.

The rewards of the painstaking transcription project are now partially available to everyone through the publication of excerpts of Mary's 18871904 diaries. However, the majority of her diary writing remains unpublished. Her fascinating later life-that is, after the death of her husband in 1904, when her public engagement and political activism increased significantly_-remains understudied. She became President of the Godalming branch of the National Union of Women's Suffrage Societies in 1909 and held a women's suffrage meeting at her home in 1913. The later years mark a transitional time in her life and identity, from devoted, progressive wife to independent, suffragist widow. To supplement their limited publication, 
I have summarized each diary below as an aid to future research. My hope is that Mary will be more widely reclaimed and celebrated as a remarkable Victorian woman artist, diarist, and suffragist.

\section{Diary of 1887}

Mary Fraser-Tytler and George Frederic Watts marry in November 1886 and begin their wedded life with an extended honeymoon, traveling to Egypt, Greece, Italy, and France, before returning to London in June 1887. This trip inspires their joint interest in different cultures and especially (for Mary) Egypt. Mary later uses her honeymoon notebooks and sketchbooks as sources for her symbolic designs, which can be seen on the walls of the Watts Cemetery Chapel (hailed as an Arts and Crafts masterpiece) and on the ceilings of the Wattses' studio-house in Surrey. Mary records the Wattses' early married life at Little Holland House in Kensington, London, where she had first met George in 1870 as an awestruck pupil. She is acutely aware of his reputation and artistic genius, as well as her own important status as his new wife (George Watts was previously married to the famous actress Ellen Terry). She is keen to support him and records a smooth integration into his circle, which includes Edward Burne-Jones, Frederic Leighton, Alfred Tennyson, George Meredith, Walter Crane, Josephine Butler, and Evelyn and William De Morgan.

\section{Diary of 1891}

The Wattses' move to their Surrey studio-house, which they name Limnerslease- "limner" being the Latin term for "artist" and "leasen" being an Old English word meaning "to glean" - in the hopes that golden years of creativity will be gleaned from this home. This Arts and Crafts house, designed by the architect Ernest George, revitalizes the Wattses' artistic lives. Terracotta decoration becomes Mary's forte (she had previously painted portraits), and she digs the seams of clay in the grounds of her new home. Mary describes her ambitious plans for the home's interior and gardens and records visits from friends and family, offering insight into the Wattses' circle and local community. Mary records the establishment of George's studio and the progression of his work, as well as her own ideas, designs, and techniques for her first ceiling panel. She plans to decorate the drawing room ceiling with symbolic white gesso panels, having developed an interest in gesso and terracotta as a student at the coeducational Slade School of Art and National Art Training School in South Kensington. Mary records the Wattses' evening readings on ancient beliefs and civilizations. In London, George paints the portrait of the socialist and women's 
suffrage supporter Walter Crane, which he later adds to his Hall of Fame (a collection of portraits of his famous contemporaries, bequeathed to the National Portrait Gallery in 1895); Mary describes their animated conversations during his sittings.

\section{Diary of 1893}

Mary records the Wattses' happy evening readings (on ancient cultures and religions as well as Jane Austen's novels and contemporary fiction) in the "niche," their private reading alcove that she designed in the living room at Limnerslease; the niche amplifies the sound of her reading to aid her older husband's deafness. Mary finishes her elaborately painted gesso decorations for the niche. They become "intensely interested" in the New Woman novels by Meredith, who this year sits for his portrait to be painted by George for his Hall of Fame (31 March). Mary records her lively, passionate discussions with Meredith about women, which excite her strongest expressions of feminist feeling: "The hope of the future lies greatly in the fact that woman is now beginning to take her place" (4 April). Mary's young niece and nephew visit; she adores them and laments that she has no young children of her own. George works on his painting Eve Repentant (1865-1897), the second of his three famous Eve paintings. The Wattses go to London in the summer to see George's work in several exhibitions, and Mary devises new ways to support financially the struggling Home Arts and Industries Association.

\section{Diary of 1896}

Much of this diary is missing; the pages from January to August have been cut out, probably by the Wattses' adopted daughter Lilian (Lily) Chapman, who was in possession of the diaries for some time after Mary's death. The reason for this editing is unknown. It is possible that the excised pages offered clues to Lily's parentage (which remains a mystery), or she may have been attempting to censor intimate or radical content so as to preserve the family's reputation. In the pages that remain, Mary details her work on the Watts Cemetery Chapel decoration with the help of villagers. She records visits from famous figures in artistic, literary, and feminist circles, including William and Edith Holman Hunt, Walter Crane, and Josephine Butler. Mary records her discussions and correspondence with Butler in great detail, directly quoting her. The English sculptor Alfred Gilbert sits for his portrait to be painted by George, who also works on his famous large-scale paintings Time, Death and Judgement (1900) for the nave of St. Paul's Cathedral and The Court of Death (1870-1902). Several of the Wattses' friends die during this year, including Leighton and William 
Morris (his funeral is described). Mary finishes her plasterwork ceilings at Limnerslease and designs the "Garment of Praise"-the decoration above the door to the Watts Cemetery Chapel; the chapel bell is also installed. Mary's pottery classes attract an increasing number of villagers, female and male, who help build the chapel. Mary sees her first Celtic manuscript in the British Museum (the Lindisfarne Gospel), which influences her design ideas for her chapel friezes. She had already been inspired by Celtic symbols in northern Scotland during her childhood. Mary buys a bicycle, which was then controversial: "My love very happy this morning because I had my 1 st turn on my bicycle ... . I feel sure it will give me new power" (3 November).

\section{Diary of 1898}

The Wattses stay in Surrey for most of this year. Mary records her anxieties about her elderly husband's poor health. George works on several paintings (portraits of Cecil Rhodes and Lord Roberts) as well as his sculpture of Tennyson (poet laureate, 1850-1892), commissioned for Lincoln Cathedral. The Wattses are affected by the death of William Gladstone and more so by the death of Burne-Jones, whose funeral is described. The building and decoration of the Watts Cemetery Chapel exterior is completed, and consecrated; towards the end of the year, Mary starts designing the decoration for the chapel interior. Suffering from exhaustion, she goes to stay on her family estate in the Highlands-Aldourie Castle, which stands on the shores of the Loch Ness-where she spent her childhood. Mary records her feelings and thoughts on her return to her Scottish homeland. George works on his plan to create a memorial to ordinary people who sacrificed themselves to save others from death-the Watts Memorial to Heroic Self-Sacrifice in Postman's Park, Aldersgate, London-and first visits the site on 4 October with Mary. Unlike war memorials that honor almost exclusively the deeds of men, this memorial recognizes men and women. Mary designs interior decoration for her chapel and plans to start a pottery business, making gravestones, sundials, garden pots, and ornaments. The first Compton Pottery pieces are made before the end of this year, and the company remains in production for over fifty years.

\section{Diary of 1902}

This is a shorter diary with shorter entries, perhaps because Mary is preoccupied with her work and caring for George. According to Mary's wishes, plans form for the building of a gallery with George's collection on permanent public display. She decides to start another pottery business close to Aldourie Castle in Scotland since her Compton Pottery in 
Surrey is successful and will soon be selling garden ornaments to Liberty of London. Mary was one of the first women to be acknowledged for her designs by this prestigious company. George finishes The Court of Death and his famous sculpture Physical Energy (1902) and works on painting Progress (1888-1904). Mary works on the interior of the Watts Cemetery Chapel, specifically on the roundels held by the angels symbolising binary opposites, positive and negative. She completes "Joy and Sorrow," "Spirit and Flesh," and "Real and Ideal," and works on the coloring of the angels' clothing.

\section{Diary of 1904}

Mary records the completion of the Watts Cemetery Chapel, and George finishes a smaller version of his painting The All-Pervading for the altar-piece. The diary soon reflects Mary's preoccupation with George's illness and death in July and her ensuing grief. She records his physical and psychological state on his deathbed; his otherworldly visions and poignant words to Mary are of particular note. In his final moments, he begs her to read to him, and she reads aloud Tennyson's In Memorium, A. H. H. (1849) - first reciting from memory and then reading from the Holman Hunts' copy. After George's funeral at the chapel and the memorial service at St. Paul's Cathedral, Mary and the Wattses' adopted daughter Lily leave for the countryside and coast to avoid visitors. Mary records her devastation but also her strength and determination to continue her work in the wake of his death. She resumes her work on her designs (for a sundial and the faces of the chapel angels) in August and continues to work with her pottery apprentices. She sorts and moves books, pictures, and sculptures from Little Holland House (which is rented out) to Limnerslease. Mary designs and creates the "flower in the crannied wall" for the hand of George's colossal Tennyson statue. ${ }^{6}$ She also varnishes several of George's paintings and commissions Frederick Hollyer to photograph much of his work.

\section{Diary of 1906-1908}

Mary continues her creative work, which she knows would please George. She plans to extend the chapel grounds and create a beautiful cloister and garden within them. She oversees the placement of George's last pictures in the gallery (now Watts Gallery) before people visit to see his work. She records her careful design of the gallery to reflect her husband's greatness. Mary begins her banner Our Lady of the Snows (1906) "to be given by the Queen to the children of Canada." She was commissioned to design decorative banners as state gifts to Canada in 1903 and 1907. Lily has a minor operation, and Mary records the emotional episode; she 
subsequently has a "sad dream" about Lily's death (8 October). She records a meeting with the De Morgans, another marriage of Art and Craft artists. George had called Evelyn "the first woman-artist of the day-if not of all time," and William had recently become a celebrity as the author of Joseph Vance (1906), to which Mary refers. ${ }^{7}$ More visitors come to the Gallery and enjoy it. Mary spends Christmas at her Aldourie family home and describes Scotland's beauty. Finally, the extended land in the Watts Cemetery Chapel grounds is consecrated, and Mary describes the impressive procession upon the Holy Hill.

Mary's diaries may appeal to a wide audience of academics and scholars in the fields of English literature, art history, history, Victorian studies, women's studies, feminist and gender studies, and auto/biography studies. Study of Mary's diaries reveals her progressive sociopolitical position and relation to the women's rights movement, as well as to art, literature, and religion. Her writing can be seen as an expressive fusion and profusion of forms and genres, as poetical, political, devotional, philosophical, and auto/ biographical. Each diary inscribes different aspects of her character, including dutiful wife, creative partner, jester, and self-proclaimed "brutal taskmaster," through which an autobiographical "I," a strong sense of self, and a creative identity is developed; indeed, her diaries can be read together as a kind of fragmented künstlerroman (27 February 1893). Ideological and cultural upheavals of the period are registered, and specifically female experiences are recorded. It is possible to trace in Mary's diaries the emergence of a distinctly female iconographic vocabulary and feminist voice, which can be seen to dialogize with early and more recent feminist discourses. Study of her diaries will lead to a wider understanding of Mary Watts as a forgotten early feminist, pioneering woman artist, and neglected nineteenth-century woman writer.

LUCY ELLA ROSE is Teaching Fellow in English Literature at the University of Surrey. Her interdisciplinary dissertation, "Women in Nineteenth-Century Creative Partnerships: The 'Significant Other," examines the role of women in artistic and literary professions and partnerships and the rise of feminism through artistic and literary discourses. It focuses on the lives and works of Christina Rossetti (1830-1894), Mary Watts (1849-1938), and Evelyn De Morgan (1855-1919). She has worked for the past five years on the Mary Watts archive at Watts Gallery (Surrey), co-transcribing her diaries for publication. She gave the first of the 
Curators' Tours of the groundbreaking 2013 exhibition The Making of Mary Seton Watts. Her first monograph, Suffragist Artists in Partnership: Gender, Word and Image, focusing on the conjugal creative partnerships of Mary and George Watts, and Evelyn and William De Morgan, is forthcoming from Edinburgh University Press in 2017.

\section{NOTES}

I would like to thank the Curatorial Team at Watts Gallery—and especially Mark Bills, Dr. Nicholas Tromans, and Dr. Desna Greenhow—for supporting my archival research.

${ }^{1}$ Scholars have made recent attempts to rectify the masculinist focus on George Watts; see Veronica Franklin Gould, Mary Seton Watts (1849-1938): Unsung Heroine of the Art Nouveau (London: Lund Humphries, 1998); Gould, Watts Chapel: An Arts and Crafts Memorial (Surrey: Veronica Franklin Gould, 1993); Melanie Unwin, "Significant Other: Art and Craft in the Career and Marriage of Mary Watts," Journal of Design History, 17 (2004), 237-50; and Elaine Cheasley Paterson, "Decoration and Desire in the Watts Chapel, Compton: Narratives of Gender, Class and Colonialism," Gender and History, 17 (2005), 714-36.

${ }^{2}$ Mary Watts's diaries were unpublished until the recent volume of extracts: The Diary of Mary Watts, 1887-1904: Victorian Progressive and Artistic Visionary, ed. Desna Greenhow (London: Lund Humphries, 2016). Mary's published works include The Word in the Pattern: A Key to the Symbols on the Walls of the Chapel at Compton (London: W. H. Ward, 1905); and George Frederic Watts: The Annals of An Artist's Life, 3 vols. (London: Macmillan, 1912). She also kept her own private notebooks, sketchbooks, journals, and books labeled "miscellaneous jottings," which are held in the Watts Gallery Archives, Compton, Surrey.

${ }^{3}$ Diaries exist for 1887, 1891, 1893, 1896, 1898, 1902, 1904, and 1906-1908. These diaries together exceed 200,000 words. See "The Diaries of Mary Seton Watts," COMWG2008.4, MSW/1, box A25, Watts Gallery Archive. References will be made parenthetically in the text by date.

${ }^{4}$ Wilfrid Blunt, England's Michelangelo: A Biography of George Frederic Watts (London: Columbus Books, 1989).

${ }^{5}$ The project to transcribe Mary's diaries and publish extracts was led by Desna Greenhow. She transcribed 1891, 1893 and 1898, while I transcribed 1896, 1902, 1904, and 1906-08. Gail Naughton largely transcribed 1887, which was also revised by myself and Greenhow.

${ }^{6}$ The quote, which is part of the engraving on the base of the statue, is from Tennyson's "Flower in the Crannied Wall" (1863).

${ }^{7}$ George's praise of Evelyn is quoted in A. M. W. Stirling, William De Morgan and his Wife (New York: Henry Holt, 1922), 193. 